\title{
Evidence for a coordinate role of CD14+ antigen-presenting cells and regulatory $T$ cells in conditioning the microenvironment of metastatic lymph nodes from patients with cervical cancer
}

\author{
Marijne Heeren ${ }^{1 *}$, Bas Koster ${ }^{2}$, Sanne Samuels ${ }^{3}$, Debbie Ferns ${ }^{1}$, Dafni Chondronasiou ${ }^{2}$, Gemma Kenter ${ }^{1}$, \\ Ekaterina S Jordanova', Tanja D de Gruijl
}

From Society for Immunotherapy of Cancer 29th Annual Meeting

National Harbor, MD, USA. 6-9 November 2014

A better understanding of the microenvironment in relation to lymph node metastasis is essential for the development of effective immunotherapeutic strategies against cervical cancer.

In the present study, we investigated the microenvironment of tumor-draining lymph nodes of cervical cancer patients, by comprehensive flow cytometry-based phenotyping and enumeration of immune-cell subsets in tumor-negative ( $\mathrm{LN}-, \mathrm{n}=20)$ versus tumor-positive lymph nodes $(\mathrm{LN}+, \mathrm{n}=8)$, and by the study of cytokine release profiles $(\mathrm{n}=4$ for both $\mathrm{LN}$ - and $\mathrm{LN}+)$.

We found significantly lower $\mathrm{CD} 4^{+}$and higher $\mathrm{CD} 8^{+}$ $\mathrm{T}$-cell frequencies in $\mathrm{LN}+$ samples, accompanied by increased surface levels of activation (HLA-DR and ICOS) and inhibitory markers (PD-1 and CTLA-4). Furthermore, in $\mathrm{LN}+$ we found increased rates of a potentially regulatory antigen-presenting cell (APC) subset (CD11c ${ }^{\text {hi }} \mathrm{CD} 14$ ${ }^{+} \mathrm{PD}-\mathrm{L1}^{+}$) and of myeloid-derived suppressor cell (MDSC) subsets, which in the case of the former correlated significantly with elevated frequencies of Fox $3^{+}$Tregs. After in vitro stimulation with different TLR ligands (PGN; PolyIC; R848), we observed higher production levels of IL-6, IL-10 and TNF $\alpha$ but lower levels of IFN $\gamma$ in LN+.

We conclude that, despite increased T-cell differentiation and activation, a striking switch to a profound immune suppressive microenvironment in $\mathrm{LN}+$ of cervical cancer patients will enable immune escape. Our data point to the $\mathrm{CD} 14^{+} \mathrm{PD}-\mathrm{L} 1^{+} \mathrm{APC} / \mathrm{Treg}$ axis as a particularly

${ }^{1}$ Obstetrics \& Gynecology, VU University Medical Center, Amsterdam, The Netherlands

Full list of author information is available at the end of the article attractive and relevant therapeutic target to specifically tackle microenvironmental immune suppression and thus enhance the efficacy of immunotherapy in patients with metastasized cervical cancer.

\section{Authors' details}

'Obstetrics \& Gynecology, VU University Medical Center, Amsterdam, The Netherlands. ${ }^{2}$ Medical Oncology, VU University Medical Center, Amsterdam, The Netherlands. ${ }^{3}$ Gynecology, The Netherlands Cancer Institute, Amsterdam, The Netherlands.

Published: 6 November 2014

doi:10.1186/2051-1426-2-S3-P211

Cite this article as: Heeren et al:: Evidence for a coordinate role of CD14 + antigen-presenting cells and regulatory $T$ cells in conditioning the microenvironment of metastatic lymph nodes from patients with cervical cancer. Journal for ImmunoTherapy of Cancer 2014 2(Suppl 3):P211.

Submit your next manuscript to BioMed Central and take full advantage of:

- Convenient online submission

- Thorough peer review

- No space constraints or color figure charges

- Immediate publication on acceptance

- Inclusion in PubMed, CAS, Scopus and Google Scholar

- Research which is freely available for redistribution 